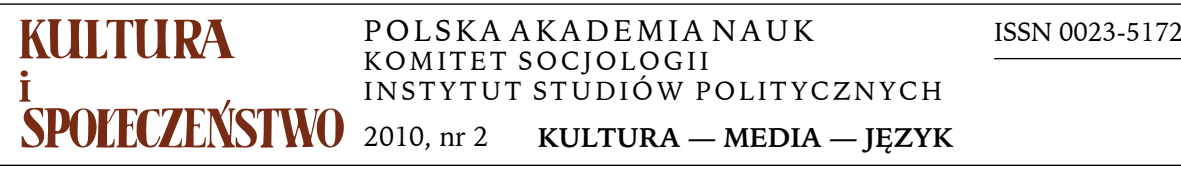

AGATA KOTOWSKA

Uniwersytet Rzeszowski

\title{
PRASA A INTERNET: KONKURENCJA CZY KOMPLEMENTARNOŚĆ?
}

Brak stałości, nieustanny ruch, pęd ku nowości, przekraczanie kulturowych i technicznych barier to cechy współczesnego świata. Charakterystyka ta dotyczy również mediów. Zmienia się rola i skala oddziaływania „starych” mediów, na znaczeniu stale zyskują nowe, a zwłaszcza supermedium, jakim jest internet. Nie tylko wydatnie wpływa on na znaczenie innych mediów i ich pozycję na rynku, ale przede wszystkim powoduje głębokie zmiany w życiu jednostek i społeczeństw. Oprócz roli niemal wszechwiedzącego informatora, generatora wszelkich treści i obrazów pełni także funkcję swoistej agory — miejsca gdzie odbywa się debata publiczna, choć artykulacja poglądów użytkownika nie musi wiązać się z ujawnieniem jego danych osobowych. Anonimowość i możliwość dowolnej kreacji własnej osoby to niewątpliwie najistotniejsze i magnetyzujące atrybuty tego medium. W tym kontekście pojawiło się pojęcie społeczeństwa sieciowego (zob. np. Bendyk 2004) czy wirtualnego, stosowane w odniesieniu do świata społeczności funkcjonujących w sieci, budowanych na wzór realnego społeczeństwa i wykazujących podobne do niego cechy, czyli na przykład społeczności zgrupowanych wokół różnego rodzaju gier online, portali tematycznych, blogów, projektów. W internecie tworzone są także namiastki realnego świata, na przykład internetowe nekropolie, za które wnosi się realne opłaty $\mathrm{u}$ administratora, czy wirtualne państwa. Można stwierdzić nawet, że obok nas powstaje drugi, równoległy świat, który często absorbuje znaczną część naszej codziennej aktywności życiowej. Co charakterystyczne, granice między tym, co publiczne, a tym, co osobiste, a nawet intymne, są w nim płynne. Można zaobserwować zjawisko masowego wirtualnego ekshibicjonizmu. Użytkownicy mediów społecznościowych kwestie prywatności postrzegają obecnie zupełnie

Adres do korespondencji: agata.kotowska@onet.eu 
inaczej niż w nieodległych czasach, gdy była ona chroniona, dostępna niewielkiej grupie bliskich osób.

Rodzi się pytanie, czy rzeczywistość wirtualna może pełnić rolę substytutu realnego świata. Obserwacja funkcjonowania współczesnych społeczeństw nie daje podstaw, by mniemać, iż realne kontakty międzyludzkie doznają uszczerbku czy są zastępowane przez te wirtualne. Jeśli tak się dzieje, to $\mathrm{W}$ stosunkowo niewielkim wymiarze ${ }^{1} \mathrm{i}$ jako konsekwencja indywidualnych dysfunkcji osobowości. Pewna część użytkowników internetu może przekładać kontakty wirtualne nad rzeczywiste, jeżeli doszło na przykład do zaburzenia prawidłowego przebiegu socjalizacji pierwotnej. Wówczas jednostka może cechować się zaniżoną samooceną, słabą odpornością na sytuacje stresowe, mieć problemy z nawiązywaniem i utrzymywaniu kontaktów interpersonalnych, okazywaniem emocji. Prawdopodobne jest wycofanie $z$ aktywnego uczestnictwa w życiu społecznym, a jego zastępczą formą staje się udział w społecznościach sieciowych. Ryzyko uzależnienia się od „relacji zastępczych” jest największe u osób, które borykają się z kompleksami, cierpią z powodu niskiego poczucia własnej wartości i częstej dezaprobaty ze strony innych (Czubakowska, Osipczuk 2002). W świecie wirtualnym zaspokajane są wówczas potrzeby, których w życiu realnym nie można zaspokoić lub jest to w znacznym stopniu utrudnione. Łatwość i szybkość realizacji celów w sieci przyczynia się do doraźnej efektywnej regulacji emocji, co tworzy iluzoryczne poczucie przyjemności i sprzyja petryfikacji patogennych zachowań.

Różnica $\mathrm{w}$ dostępie do internetu, który z założenia jest nastawiony na poszerzenie możliwości poznawczych i komunikacyjnych użytkownika, stwarza realne zagrożenie narastania różnic $\mathrm{w}$ stopniu poinformowania, co $\mathrm{z}$ kolei powoduje wykluczenie „medialnych analfabetów” z pełnego uczestnictwa w życiu społecznym i ogranicza ich szanse na rozwój zawodowy. Luka informacyjna między jednostkami $z$ różnych względów predysponowanymi do korzystania z nowych mediów a pozostałymi tworzy się i pogłębia (Goban-Klas 2008, s. 305-306). Dysproporcja w dostępie do wiedzy znajduje bezpośrednie przełożenie na kwestie ekonomiczne.

Poglądy na siłę oddziaływania mediów są zróżnicowane. Kwestią przede wszystkim nurtującą obecnie specjalistów jest kierunek wywieranego przez nie wpływu i habitus współczesnego „człowieka medialnego”. Jednostka często jest dziś ujmowana w kategoriach media victim, można skłonić się ku twierdzeniu o przemożnym wpływie mediów na życie człowieka, co wyraża się nie tylko we wskazywaniu, o czym myśleć (porządek prezentacji), ale także, co

\footnotetext{
${ }^{1}$ Według badań przeprowadzonych w 2003 r. przez Amerykańskie Centrum Uzależnień Internetowych, $6 \%$ internautów jest siecioholikami, czyli osobami korzystającymi z internetu i komputera w sposób zaburzający ich relacje z rzeczywistością. Jeśli przyjąć szacunkową liczbę internautów jako $300 \mathrm{mln}$, będzie to oznaczało, że na świecie z tym problemem boryka się co najmniej $18 \mathrm{mln}$ ludzi. (www.wiadomosci24.pl).
} 
myśleć (w konkretnych zagadnieniach) i jak myśleć (według jakich schematów czy paradygmatów dokonywać oceny rzeczywistości). Jak zaznacza Tomasz Goban-Klas (2008, s. 257), media masowe odgrywają istotną rolę w procesie nabywania (uwewnętrzniania) norm i wartości społecznych, stając się tym samym czynnikiem socjalizacji jednostki. Chodzi przy tym nie tylko o nabywanie idei społecznych, ale również sentymentów społecznych — zarówno sympatii, jak i antypatii. Proces socjalizacji, choć najważniejszy w okresie dzieciństwa i młodości, dokonuje się przez całe życie.

Barierą, która może do pewnego stopnia ograniczać ów wpływ, jest znajomość zasad działania i organizacji mediów oraz świadomość stosowanych przez nie technik propagandowych i manipulacyjnych. Jak stwierdził znany specjalista od brandingu (dział marketingu zajmujący się marką) Martin Lindstrom (2009), im więcej konsument wie o tym, dlaczego pada ofiarą reklamy, tym lepiej potrafi się przed nią bronić, choć nie ochroni go to całkowicie przed oddziaływaniem zawartych w niej sugestii. Wiedza o wykorzystywanych przez media technikach wpływu społecznego jest ze wszech miar pożądana. Jednak wielu medioznawców i przedstawicieli nauk społecznych na podstawie własnych obserwacji i badań twierdzi, że większość odbiorców i użytkowników mediów nie jest zainteresowana zgłębieniem powyższych zagadnień, co sprzyja bezrefleksyjnej percepcji emitowanych treści. Zdarza się także, że osoby znające mechanizmy działania mediów przeceniają, jak pisał Maciej Iłowiecki (2003, s. 80), wpływ mediów na innych, niedoceniają go zaś w odniesieniu do siebie. Konsekwencją uznania przez jednostkę własnej odporności na manipulację medialną (polityczną, społeczną, marketingową) jest zatracenie dystansu do prezentowanych treści, co paradoksalnie zwiększa podatność na działania manipulacyjne. Niektórzy medioznawcy postulują wprowadzenie „wychowania do mediów" już we wczesnym etapie edukacji szkolnej. Media bowiem postrzega się niekiedy jako kreatora cywilizacji i kultury, a ich rolę sprowadza do ukazywania jednostkom, jak mają myśleć i w jaki sposób porządkować rzeczywistość przez nie przetwarzaną, przy czym wpływ mediów na rozwój cywilizacyjny społeczeństw dokonuje się nie tylko za sprawą treści przez nie przekazywanych, ale również samej ich formy (Katz 1990, s. 37-38; por. Dobek-Ostrowska 2001, s. 209). Media próbują ponadto wywołać u odbiorców przeświadczenie, iż percepcja treści przez nie emitowanych jest tożsama z pełną partycypacją w życiu społecznym.

Wskazane zjawiska, choć niezwykle frapujące, nie są jednak przedmiotem tej refleksji. Jest nim problem relacji między prasą a internetem, a ściślej próba odpowiedzi na pytanie o skalę oddziaływania prasy na współczesne społeczeństwa oraz określenia „strefy jej wpływów” w odniesieniu do nowych mediów.

Jak zauważył Tadeusz Kowalski (2006, s. 100), mimo długotrwałego kryzysu czytelnictwa, prasa codzienna jest podstawowym probierzem jakości systemu komunikowania w każdym społeczeństwie. Aby w możliwie pełny sposób 
przedstawić aktualną skalę oddziaływania prasy i jej pozycję na rynku mediów, a także podjać próbę prognozowania, należy odnieść się do jej dotychczasowej roli i kontekstu funkcjonowania.

Wraz z wynalezieniem druku ludzkość wkroczyła w nową fazę cywilizacyjnego rozwoju. Pojawienie się książki drukowanej jest pierwszym etapem historii nowoczesnych mediów i przełomem w dziejach komunikowania masowego. Abstrahując od interesującego skądinąd zagadnienia wpływu tego odkrycia na rozwój Europy (Bauer 2008, s. 68-70), warto wspomnieć, że przez blisko dwieście lat był to jedyny nośnik drukowanej informacji. Pierwsze gazety zaczęły się ukazywać na początku XVII wieku, gazeta codzienna zaś w jego połowie². Początkowo miały one charakter swoistego informatora i stanowiły zbiór różnorodnych treści, a rolę redaktora, drukarza, wydawcy i dystrybutora pełnił właściciel drukarni. Jednak już pierwsze gazety nosiły cechy gatunkowe prasy, do których należy zaliczyć: regularne ukazywanie się, nastawienie komercyjne, różnorodność realizowanych celów, jak również publiczny i jawny charakter (Goban-Klas 2008, s. 18).

Pochodną rozwoju prasy, oprócz między innymi rozpowszechniania się prądów demokratycznych, formowania społeczeństwa obywatelskiego (wykształcenia zbiorowej samoświadomości, solidarności społecznej, które są jego podstawa), był także widoczny wpływ na szeroko rozumiane postawy społeczne (zwłaszcza w aspekcie kulturowym, obyczajowym), co pociągnęło za sobą szersze zainteresowanie tym medium ze strony nauki i wykształcenie się odrębnej metodologii badań prasy.

Przesłanki świadczące o formowaniu się naukowych podstaw analizy prasy można dostrzec na przełomie XIX i XX wieku. W tym właśnie okresie w piśmiennictwie przodujących wówczas krajów można było odnaleźć przykłady zastosowania statystyki w badaniach nad tekstami ${ }^{3}$. W Stanach Zjednoczonych rola analizy zawartości prasy wzrastała stale od lat trzydziestych XX wieku, by osiągnąć rozkwit w latach pięćdziesiątych. Zastosowanie komputerów do analizy treści w latach sześćdziesiątych wprowadziło ją w zakres badań komunikowania międzynarodowego i porównawczych badań kulturowych (Pisarek 1983, s. 40).

$\mathrm{Na}$ ziemiach polskich początki naukowej analizy zawartości prasy sięgają drugiej połowy wieku XIX (studium na temat wątków przemocy w prasie autorstwa Jana Władysława Dawida opublikowane w 1886 r.), a nawet okresu

2 Pierwsza gazeta drukowana w Polsce — „Merkuriusz Polski” — została wydana z inicjatywy króla Jana Kazimierza i jego żony Marii Ludwiki w Krakowie 3 stycznia 1661 r. przez Jana Aleksandra Gorczyna i Hieronima Pinocci; zob. Encyklopedia Krakowa, Wydawnictwo Naukowe PWN, Warszawa-Kraków 2000, s. 606.

3 We Francji była to praca Henriego de Noussance (1902), w Niemczech - Paula Stoklossy (1910) oraz Otto Grotha, w Stanach Zjednoczonych - Johna G. Speeda (1893). Prekursorami analizy zawartości w tradycji marksistowskiej byli Karol Marks (m.in. artykuł w „Neue Rheinische Zeitung” z 1848 r.) oraz Włodzimierz Lenin (praca z 1914 r.); zob. Pisarek 1983, s. 39. 
wcześniejszego (historycy prasoznawstwa skłonni są zaliczyć do tego typu badań także prace Edwarda Dembowskiego i Henryka Kamieńskiego z lat 1841-1843; Pisarek 1983, s. 38).

Analiza zawartości prasy, której cechą charakterystyczną jest połączenie podejścia ilościowego i jakościowego, to metoda o ugruntowanej pozycji w naukach humanistycznych. Zainteresowanie tym typem badań w socjologii wynika zapewne $z$ dostrzeżenia $\mathrm{w}$ życiu społecznym roli prasy — jako czynnika przez długi czas fundamentalnego dla „konstruowania” rzeczywistości, czyli wyznaczania problematyki istotnej dla jednostek i społeczeństw (selekcja informacji, nadawanie im rangi itp.), a także, a może przede wszystkim, dla kształtowania postaw wobec tematów ważkich.

Analiza prasy zawsze była i jest nadal podstawowym narzędziem w tzw. białym wywiadzie, czyli pozyskiwaniu informacji ze źródeł otwartych (jawnych), dziś należy uwzględnić także internet, z czego korzysta się zarówno w polityce, jak i gospodarce, a szczególnego znaczenia nabiera w dobie gospodarki globalnej, kiedy informacja (wiedza) jest podstawą podejmowania wszelkich decyzji. Również na polu naukowym właściwie nie sposób wskazać dziedziny, która nie odniosłaby korzyści z przeglądu i analizy prasy. Dla przedstawicieli nauk społecznych (socjologii, historii, psychologii, pedagogiki, politologii, stosunków międzynarodowych itp.) elementarne znaczenie ma bieżący monitoring mediów, w tym zwłaszcza prasy, służący rejestrowaniu zjawisk (czy ich symptomów) politycznych, gospodarczych, kulturalnych w istotny sposób wpływających na jednostkę i społeczeństwa, mechanizmów sprawowania władzy politycznej, jej degeneracji, funkcji i sposobu organizacji państwa, założeń i metod prowadzenia polityki międzynarodowej, określenia kontekstu działań i interesów partnerów stosunków międzynarodowych itp. Niezwykle ważna jest także analiza zawartości prasy pod kątem stosowanych technik manipulacyjnych, kształtowania opinii publicznej w kwestiach szczegółowych czy prób wpływania na świadomość historyczną. Przegląd i analiza prasy bywa często impulsem do głębszej refleksji nad konkretnym zagadnieniem lub do pogłębionych badań naukowych.

Prasa jest medium specyficznym, którego analiza, jeżeli jest przeprowadzona rzetelnie, zawsze daje pogłębiony obraz wycinka rzeczywistości społecznej. Jej znaczenie i specyfika wynika z następujących faktów:

1. Prasa jest obszarem dominacji logosfery, obrazy stanowią w niej jedynie element komplementarny w stosunku do słów. Dostarcza obszernego i bogatego materiału badawczego, ma ponadto wysoką zdolność oddziaływania na postawy i opinie ludzkie (ujawnia się w ten sposób jej funkcja pedagogiczna i propagandowa).

2. Jeżeli chodzi o skuteczność w informowaniu jak największej liczby odbiorców, to prasa codzienna zajmuje drugie miejsce (po telewizji). Jednak jeśli chodzi o zawartość szczegółów istotnych dla danego zagadnienia, wysuwa się na miejsce pierwsze. Bardziej wnikliwe czy rozległe ujęcie danego zagadnie- 
nia i sprecyzowanie stanowiska na konkretny temat (przez rozwinięcie argumentacji) w szerszym zakresie często możliwe jest jedynie na łamach prasy. $\mathrm{W}$ mediach elektronicznych — radiu, telewizji - programy informacyjne stanowią ułamek całej oferty kierowanej do odbiorców oraz podlegają wyraźnym ograniczeniom czasowym (wypowiedzi są, często z konieczności, lakoniczne, co może spłycić podejmowany problem). W mniejszym stopniu prasa pełni funkcję rozrywkową.

3. Prasa wpływa - co prawda, wolniej niż media audiowizualne - na poglądy, odczucia czy zachowania odbiorców, a skutki jej oddziaływania są długotrwałe (wiąże się to $z$ koniecznością podjęcia przez odbiorcę wzmożonego wysiłku intelektualnego $\mathrm{w}$ celu zapoznania się z treścią przekazu czy refleksji nad nim, co sprawia, że pogłębione staje się rozumienie odbieranych tekstów). Pozwala to jednocześnie - inaczej niż w przypadku mediów audiowizualnych, które cechuje ulotność - na przeprowadzenia pogłębionej analizy.

4. Na łamach prasy częściej niż $\mathrm{w}$ innych mediach podnoszone są kwestie natury moralnej oraz palące problemy społeczne (zob. Lepa 2003).

5. Prasa skutecznie wpływa na człowieka w warstwie kulturalnej, formując zwłaszcza postawy.

6. Istotny jest także większy dostęp do źródeł (w przypadku mediów elektronicznych istnieją wyraźne utrudnienia w tym zakresie).

7. Także z punktu widzenia działań marketingowych prasa ma wiele zalet. Umożliwia przeprowadzenie kampanii o selektywnym zasięgu - w wybranych regionach lub $\mathrm{w}$ danych miastach przez prasę regionalną czy lokalne sekcje pism ogólnopolskich, przez prasę specjalistyczną. Gwarantuje pewne, precyzyjne dotarcie do grup docelowych. Również wyprodukowanie reklamy prasowej jest często znacznie szybsze i mniej kosztowne niż na przykład przygotowanie spotu telewizyjnego. Choć gazety mają krótki cykl życia, reklama w prasie ma dłuższy żywot, gdyż odbiorca nierzadko dłużej przechowuje pismo, zwłaszcza hobbystyczne czy branżowe, i wraca do numeru archiwalnego.

W dobie cyfryzacji mediów prowadzenie przeglądu prasy lokalnej, ogólnokrajowej czy międzynarodowej jest zdecydowanie mniej skomplikowane, gdyż coraz więcej tytułów ma swoje elektroniczne odpowiedniki w sieci. Odbiorca może $\mathrm{w}$ internecie przeczytać tekst $\mathrm{w}$ orginale $\mathrm{w}$ czasie równoległym do wydania papierowego, a także dotrzeć do streszczeń i omówień artykułów oraz polemik. Przeprowadzenie pełnej analizy zawartości na podstawie elektronicznych wydań prasy nastręcza jednak pewnych trudności (nie można np. ocenić ekspozycji materiałów, rozmiaru artykułów czy zdjęć i innych parametrów tekstu, takich jak wielkość czcionki).

Wróćmy jednak do relacji między prasą a internetem. Podstawowym problemem są szanse prasy na współczesnym rynku medialnym i kierunek jej przemian wynikających $z$ komercjalizacji oraz w obliczu tych zmian, skala i rodzaj wpływu na audytoria. 
Charakterystyczne dla współczesnych społeczeństw jest przenikanie się kultur, ujednolicanie stylów życia, wartości. Nowe media przyczyniają się do promowania i utrwalania tej tendencji. Dzięki ich mobliności i interaktywności nowe zjawiska błyskawicznie się upowszechniają. Mamy do czynienia z kulturą konwergencji, którą błyskotliwie opisał Henry Jenkins (2007). Prognozy głoszące zmarginalizowanie starych mediów przez nowe jednak się nie potwierdziły. Stare i nowe media wchodzą w coraz bardziej skomplikowane interakcje, niektóre wytwarzane „samorzutnie” (oddolnie), inne jako odpowiedź na potrzeby rynku. Przykładem interakcji pierwszego typu jest tworzenie się w sieci społeczności fanowskich wokół książek, filmów czy programów telewizyjnych ${ }^{4}$, drugiego typu zaś - wdrażanie przez specjalistów od marketingu programu telewizji interaktywnej $\mathrm{w}$ internecie lub wprowadzanie do oferty programowej produkcji, które pobudzają aktywność odbiorców.

Za mało prawdopodobny należy uznać scenariusz odejścia prasy jako gatunku w niebyt. Prasa i internet będą raczej koegzystować, koncentrując działalność na odmiennych płaszczyznach. Wydaje się, że prasa nadal będzie pełnić swoją informacyjną i opiniotwórczą rolę, choć skala jej wpływu z pewnością $\mathrm{z}$ czasem się zmieni, internet bowiem również ma $\mathrm{w}$ tym względzie niemałe i stale rosnące znaczenie. Jak zauważa Tadeusz Kowalski (2006, s. 117), analiza tematyczna serwisów radiowych i telewizyjnych oraz serwisów on-line prowadzi do wniosku, że znaczna część bieżących zagadnień ma początek w publikacjach prasowych. Dodaje jednak, że tylko prasa prestiżowa utrzymuje rolę lidera opiniotwórczego wśród mediów, prasa popularna koncentruje się głównie na sensacji i erotyce, w mniejszym stopniu na relacjonowaniu i komentowaniu aktualnych wydarzeń.

Internet dostarcza szeroko rozumianej informacji, w tym także bieżącej, choć często nie tak szczegółowej jak prasa. Materiały, które się w nim pojawiają, w wielu przypadkach mają eklektyczny charakter, są kompilacją informacji z różnych mediów, swoistym résumé. Faktem jest jednak utrata przez prasę monopolu na newsy. Odbiorca bowiem nie tylko nie musi czekać do następnego wydania gazety, aby poszerzyć swoją wiedzę czy zaspokoić ciekawość, może także natychmiast wyartykułować swoje zdanie na temat przeczytanego materiału lub wdać się $\mathrm{w}$ polemikę $\mathrm{z}$ innymi odbiorcami, użytkownikami forum. Daje to zupełnie nową jakość w dziedzinie odbioru informacji medialnej. W chwili obecnej trudno dowieść, czy internet kreuje opinię publiczną na szerszą skalę, choć jego funkcja informacyjna jest zupełnie czytelna. Rola tego medium w omawianym zakresie prawdopodobne będzie rosła $\mathrm{w}$ miarę osiągania wieku produkcyjnego przez te pokolenia, dla których internet jest źródłem

${ }^{4} \mathrm{O}$ tym zjawisku pisał szerzej przywołany Henry Jenkins, ale także m.in. Piotr Siuda w artykule Fanfiction - przejaw medialnych fandomów (2007), gdzie przedstawił twórczość fanów opartą na już istniejących produktach kultury popularnej. Społeczności skupiające fanów określane są przezeń mianem fandomów. 
informacji tak naturalnym jak dla współczesnych gazeta. Nie jest pewne, czy „pokolenia nowych mediów” będą miały nawyk czytania prasy w takim zakresie jak ludzie dzisiaj. Obecnie wydaje się, że znaczna część użytkowników internetu koncentruje się raczej na innych jego funkcjach. W medium tym daje się zaobserwować daleko posunięte epatowanie sensacją i tabloidyzacja, o czym świadczy nagminnie stosowana na portalach internetowych technika manipulacji nagłówkami i lidami. Treść materiału często zupełnie odbiega od sensacyjnie brzmiącego nagłówka. Wynika to z komercyjnego nastawienia, a ściślej $z$ faktu, iż zabiegi takie podnoszą ceny reklam zamieszczanych przy poszczególnych materiałach.

Istotne jest pytanie o pozycję rynkową prasy. Nie jest tajemnicą, że od wielu lat popyt na prasę codzienną jest jedną z najpoważniejszych trosk wydawców europejskich i amerykańskich. Liczba sprzedawanych egzemplarzy sukcesywnie spada. Spada zainteresowanie czytelników lekturą gazet, ale zagrożeniem fizycznego bytu tego medium są także: utrata wpływów z reklam oraz zmniejszające się dochody z zamieszczania ogłoszeń drobnych (portale internetowe stopniowo zastępują gazety w tym względzie). Długotrwała kryzysowa sytuacja w omawianym sektorze powoduje, że wejście na rynek prasy jest obecnie dość ryzykowne (w polskich realiach nie powiodła się na przykład próba wprowadzenia na rynek w 2005 r. przez spółkę Agora S.A. dziennika „Nowy Dzień”, ale już „Dziennik Polska-Europa-Świat”, od kwietnia 2006 r. wydawany przez Axel Springer Polska, zdołał się na nim odnaleźć ${ }^{5}$ ) i nie gwarantuje wysokich zysków, zwrot inwestycji (a ta jest niemała) może znacznie rozciągnąć się w czasie.

Nie wszyscy zainteresowani problemem przedstawiają optymistyczne scenariusze. Część badaczy mediów i analityków rynku medialnego twierdzi, że prasa $\mathrm{w}$ dotychczasowym kształcie nie ma szans na przetrwanie. Na uzasadnienie tych prognoz podają wiele argumentów. Philip Meyer (2004) przewiduje, że ostatnia gazeta w formie papierowej zostanie wydana w roku 2043 (co, jak wcześniej zaznaczyłam, nie oznacza śmierci gazet jako medium) (zob. Stasiak 2006). Bill Gates w wywiadzie dla „Le Figaro” z 26 października 2005 r. przewidywał, że za pięć lat liczba osób czytających prasę w internecie wzrośnie do $40-50 \%$. Podkreślił, że warunkiem przetrwania dzienników tradycyjnych jest zadbanie o jakość ich stron internetowych ${ }^{6}$. Obawy wydawców gazet papierowych o wynik konkurencji z internetem są jak najbardziej uzasadnione. Problem dotyczy nie tylko gazet, ale także tygodników. Amerykańskie badania Media Life z 2005 r. wykazały, że zagrożona jest egzystencja co trzeciego tytułu na rynku. Potęga nowego medium rośnie wraz z upowszechnieniem dostępu do szerokopasmowego internetu. Liczba osób korzystających z internetu codzien-

\footnotetext{
5 „Dziennik Polska-Europa-Świat” był wydawany od 18 kwietnia 2006 r. do 12 września 2009 r. W wyniku jego połączenia z „Gazetą Prawną” powstało później czasopismo „Dziennik Gazeta Prawna” (wydawane od 14 września 2009 r.).

${ }^{6}$ www.wiadomosci.mediarun.pl [27.10.2005].
} 
nie lub niemal codziennie stale się zwiększa, a to właśnie ta grupa internautów poświęca aż 49,70\% czasu spędzonego w sieci na korzystanie $z$ internetowych wydań gazet i magazynów ${ }^{7}$. Na rynku informacji coraz większą rolę odgrywają portale internetowe, których dochody z reklamy systematycznie rosną, co powoduje jednocześnie odpływ środków zasilających do tej pory tradycyjne wydawnictwa (Paprocka 2005).

Spadek poczytności tradycyjnych gazet na rzecz serwisów internetowych przekłada się na wyniki finansowe wydawnictw, które tracą nie tylko środki z reklamy, a także odbiorców. Ustalono, że w drugim kwartale 2008 r. przychody reklamowe mediów w ujęciu netto wzrosły o 11,9\% względem analogicznego okresu roku poprzedniego. Najwyższe wpływy z reklamy zanotowała tradycyjnie telewizja, której przychody zwiększyły się o 11\%. Zgodnie z oczekiwaniami analityków, najwyższą dynamikę osiągnęła reklama internetowa, której wartość w badanym okresie wzrosła o $42 \%$, a najniższą — reklama prasowa ${ }^{8}$.

Na rynek prasy drukowanej niebagatelny wpływ będzie mieć zapewne także rozpowszechnienie przenośnych czytników e-książek (e-booków). Choć rozpowszechnienia się e-gazety nie należy się spodziewać w ciągu najbliższych kilku lat, pomysł krąży w branży przynajmniej od dekady (Grynkiewicz 2006) i trzeba liczyć się z jego stopniowym rozwojem, wreszcie ekspansją (wprowadzenie e-papieru oznacza dla wydawców wymierne korzyści ekonomiczne - oszczędność na druku i dystrybucji). W październiku 2007 r. premierę miał produkt wyprodukowany przez Sony, w listopadzie 2007 r. — produkt firmy Amazon. Oba zostały wyposażone w ekrany E-Ink, których technologia pozwala na czytanie tekstu bez przemęczania oczu. Tradycyjne wyświetlacze świecą, co przy intensywnym czytaniu męczy oczy. Zastosowanie e-papieru ma zaś tę zaletę, że tekst jest widziany w świetle odbitym, jakbyśmy czytali zwykłą papierową gazetę. Ceny powyższych urządzeń w momencie ich wprowadzenia na rynek wahały się od 350 do 399 dol. Dostępne będą najpierw na rynku amerykańskim, w Polsce z pewnością za kilka lat.

W ślad za pionierami we wprowadzaniu urządzeń do czytania e-booków poszły i inne firmy. Obecnie jest ich na rynku około jedenastu. Wyposażone są w pamięć umożliwiającą zapisanie kilkuset tytułów, można za ich pomocą korzystać z internetu, robić odręczne notatki, odtwarzać pliki muzyczne (Sowula 2008). Taki sposób korzystania $z$ oferty rynku prasowego z pewnością się upowszechni.

Wyniki badań Jupiter Research z 2006 r. wskazują, że 24\% osób w wieku 35-44 lata czytuje newsy on-line, $\mathrm{w}$ formie tradycyjnej zaś czyta je zaledwie $19 \%$ tej kategorii wiekowej. Dla osób młodych, w wieku 18-24 lat, charakterystyczny jest brak zainteresowania prasą jako medium informacyjnym - tylko $13 \% \mathrm{z}$ nich czytuje informacje dostępne on-line, zaledwie $2 \%$ jest czytelnikami

\footnotetext{
${ }^{7}$ Megapanel PBI/Gemius, kwiecień 2005.

8 Badania przeprowadzone przez CR Media Consulting S.A. (www.crmc.pl).
} 
gazet. Nie dziwi fakt, że dane dotyczące osób starszych wyglądają zupełnie inaczej. Gazety drukowane czyta aż $41 \%$ osób w wieku powyżej 55 lat $^{9}$. W świetle wyników badań działania propagujące czytelnictwo prasy powinny się koncentrować na osobach w młodym wieku, nie mających nawyku jej czytania. Do pionierskich inicjatyw tego typu należy zaprezentowany we Francji pod koniec października 2009 r. plan „Moja darmowa gazeta”, którego celem ma być ratowanie rynku prasowego w tym kraju oraz poprawa wyjątkowo złej kondycji czytelnictwa wśród młodych ludzi. Założono że rząd francuski każdej chętnej osobie w wieku 18-24 lat sfinansuje roczną prenumeratę dowolnej francuskiej gazety, $\mathrm{w}$ programie weźmie udział 60 gazet, a władze przeznaczą na ten cel $\mathrm{w}$ ciągu najbliższych trzech lat 15 mln euro ${ }^{10}$. Na wprowadzenie w życie tego typu rozwiązań oczywiście mogą sobie pozwolić państwa, w których obserwacja i analiza niepokojących zjawisk społecznych idzie w parze z zasobnością budżetu.

Kurczenie się rynku prasowego nie ominęło również Polski. Według raportu Wirtualnemedia.pl, w lipcu 2008 r. spadła sprzedaż siedmiu ogólnopolskich dzienników. Swój wynik poprawiły tylko dwa tytuły: „Super Express” i „Gazeta Prawna”. Liderem sprzedaży ogółem dzienników ogólnopolskich pozostał „Fakt”, wydawany przez Axel Springer Polska, mimo że według danych Związku Kontroli Dystrybucji Prasy opracowanych przez portal Wirtualnemedia.pl sprzedaż tej gazety w lipcu 2008 r. wyniosła 491797 egz., o 4\% mniej niż w analogicznym okresie $2007 \mathrm{r}$. Średnia sprzedaż zajmującej drugie miejsce „Gazety Wyborczej” (Agora) wyniosła 367122 egz., co stanowi wynik o 12,2\% gorszy niż w lipcu 2007 r. Na trzecim miejscu utrzymał się „Super Express” (Murator), który podniósł swoją sprzedaż o 1,5\% — do 199440 egz. W dalszej kolejności uplasowała się „Rzeczpospolita” (Presspublika), która zanotowała spadek o 9\%. W lipcu 2008 r. tytuł sprzedał się w ilości 131103 egz. Na piątym miejscu znalazł się „Dziennik” (Axel Springer Polska) ze średnią sprzedażą ogółem wynoszącą 88812 egz. (spadek o 50\%) ${ }^{11}$.

Tendencja spadkowa utrzymała się także w następnych latach. W lipcu 2009 r. zmniejszyła się sprzedaż wszystkich dzienników ogólnopolskich — najwięcej stracił „Dziennik” (spadek o 18\%) i „Parkiet”, najmniej „Super Express” (spadek o 4\%) i „Fakt”, który w lipcu miał sprzedaż niższą o 5\%, ale pozostał liderem w sprzedaży ogółem dzienników ogólnopolskich. Znaczny spadek sprzedaży odnotowały również "Gazeta Wyborcza” zajmująca drugie miejsce (o 14\%) oraz zajmująca miejsce czwarte „Rzeczpospolita” (o 16\%) ${ }^{12}$.

Okresem wyjątkowym pod względem sprzedaży dzienników ogólnopolskich był kwiecień 2010 r., kiedy sprzedaż wzrosła w porównaniu z analogicznym miesiącem 2009 r. (oprócz „Gazety Wyborczej”, która jako jedyna straciła

\footnotetext{
${ }^{9}$ www.money.pl [09.06.2007].

10 Wiadomości TVP 1 [28.10.2009].

11 www.wirtualnemedia.pl [04.09.2008].

12 www.wirtualnemedia.pl [04.09.2009].
} 
$\left.1,5 \%{ }^{13}\right)$. Wzrost sprzedaży spowodowany był katastrofą lotniczą w Smoleńsku, wydarzeniem bez precedensu, o wielkiej randze dla narodu i państwa polskiego. Dowodzi to znacznego zaufania społecznego do rzetelności i kompletności informacji zamieszczanych przez prasę. Należy jednak zaznaczyć, że ożywienie na rynku prasowym miało charakter incydentalny i nie oznacza odwrócenia utrzymującej się w Polsce od lat niekorzystnej tendencji kurczenia się liczby odbiorców.

Liderem sprzedaży dzienników ogólnopolskich ogółem (w kioskach i prenumeracie) w kwietniu 2010 r. był „Fakt”. Sprzedaż gazety wyniosła 500533 egz., o 5\% więcej niż w analogicznym okresie 2009 r. Na miejscu drugim uplasowała się „Gazeta Wyborcza” (mimo spadku sprzedaży), dalej „Super Express” (wzrost o 7\%), „Rzeczpospolita” (wzrost o 5\%), na miejscu piątym zaś „Dziennik Gazeta Prawna" (Infor Biznes), który jesienią 2009 r. zastąpił na rynku „Dziennik” oraz „Gazetę Prawną” — jego średnia sprzedaż ogółem wyniosła 94003 egz., czyli 14 tys. więcej niż w kwietniu 2009 r. wynosiła sprzedaż "Gazety Prawnej” 14.

Sposobem na wyjście z kryzysu na rynku gazet jest, zdaniem części ekspertów, przeorientowanie prasy na rynki lokalne. Eksperci ci powołują się na wysoką sprzedaż regionalnych dzienników w Stanach Zjednoczonych. Jednak obserwując utrzymujący się na rodzimym rynku w dłuższej perspektywie czasowej sukcesywny spadek sprzedaży zdecydowanej większości dzienników regionalnych (czyli sytuację analogiczną jak w przypadku dzienników ogólnopolskich), można żywić uzasadnione obawy, czy jest to właściwy kierunek działania.

Innym ze sposobów podtrzymania rynku jest kolportaż gazet bezpłatnych, które zaczęły się pojawiać na dużą skalę od połowy lat dziewięćdziesiątych, a także komercjalizacja zawartości prasy, nie tylko co do zamieszczanych treści, ale także ze względu na formę. Nastawienie się na usługi dodatkowe, czyli oferowanie tzw. wrzutek, gadżetów, wydań specjalnych, kart konkursowych, poradników, informatorów, materiałów edukacyjnych itp., powoduje, że dla pewnej grupy odbiorców prasa staje się dodatkiem, niemal opakowaniem (Kowalski 2006, s. 127-128). Działania te przynoszą wymierne efekty i jawią się jako stała forma marketingu.

Warto zastanowić się nad tym, dlaczego prasa jako medium traci odbiorców i jakie będą społeczne skutki tego zjawiska.

Odpowiedzi należałoby szukać w szerszej perspektywie, koncentrując uwagę przede wszystkim na kulturowym wymiarze procesu globalizacji, unifikacji (homogenizacji, konwergencji) kultur, stylów życia (zasadzających się w głównej mierze na hedonizmie) oraz pragnieniach i celach, które niepodziel-

13 Szczególnie trudnym miesiącem dla „Gazety Wyborczej” był marzec 2010 r., kiedy to jej średnia sprzedaż okazała się ponad 17\% niższa niż w marcu 2009 r. Był to najsłabszy od lat wynik gazety.

14 www.wirtualnemedia.pl [08.06.2010]. 
nie wyznacza konsumpcja. Stymulowanie konsumpcyjnych zachowań w dobie wielkiego kryzysu $z$ lat trzydziestych XX wieku było zresztą uznawane przez ekonomistów za panaceum na palące problemy gospodarcze. We wzroście globalnego popytu upatrywali oni szansy na osiągnięcie stanu równowagi w gospodarce. $Z$ pewnością nie przewidzieli jednak, że konsumpcja może stać się celem samym w sobie, przedmiotem kultu, jedyną wartością. Hedonizm i konsumpcjonizm są zjawiskami, które, choć mogą się wydawać pozornie odległe od czytelnictwa prasy, wzmacniają niechęć do działań wymagających pewnego wysiłku, także intelektualnego. Hedonistyczne nastawienie do życia, skoncentrowanie się na własnych doznaniach, osiąganiu przyjemności, rozrywce, jest bezpośrednio skorelowane $z$ niechęcią do refleksji nad problemami społecznymi, a jeśli jest ona podejmowana, to tylko w indywidualnym kontekście. Alan Durning (1992) pisząc o reklamie jako najistotniejszym elemencie walki o konsumenta wskazał, że jej głównymi cechami są: propagowanie hedonizmu, gloryfikacja jednostki oraz ukazywanie konsumpcji jako sposobu na samorealizację. Reklama wizualizuje "nasze” pragnienia, wskazuje „pożądany” styl życia i pogłębia stan niezadowolenia czy nawet niespełnienia życiowego, kiedy nie możemy sprostać coraz to nowszym konsumpcyjnym wyzwaniom.

Wszechobecna konsumpcja, orientująca jednostkę na „mieć”, a nie na „być”, pozostaje nie bez wpływu na jej preferencje medialne. Widoczny jest odwrót od bardziej wymagających mediów, czego widocznym przejawem jest między innymi likwidacja bibliotek. Warto pamiętać jeszcze, że w dobie kryzysu gospodarczego w sytuacji niestabilności finansowej gospodarstw domowych następuje redukcja kosztów utrzymania, przy czym w pierwszej kolejności cięciom podlegają wydatki na potrzeby wyższego rzędu, do jakich zalicza się między innymi aktywną partycypację w kulturze czy życiu społecznym. Dalsze zmniejszenie sprzedaży prasy staje się więc tym bardziej prawdopodobne, że korzystanie $z$ internetu jako konkurencyjnego medium często jest bezpłatne lub wymaga minimalnych kosztów.

Wszystko to może wpływać na osłabienie wrażliwości społecznej, zmniejszenie nacisku na rozwój intelektualny, wreszcie - alienację osób nie mogących lub nie chcących sprostać współczesnym wymaganiom partycypowania w społeczeństwie jedynie według wytyczonych przez media „standardów posiadania”. Kultura, w tym także kultura medialna, została „spłaszczona” i w coraz większym stopniu opiera się na niewyszukanych formach rozrywki i sensacyjnej informacji, co najlepiej egzemplifikuje skala oglądalności programów telewizyjnych o takim profilu, zawartość programów informacyjnych (ich treść i rangowanie poszczególnych informacji - często niekoniecznie według kryterium rzeczywistego znaczenia), a także fakt, że ogólny spadek sprzedaży prasy, w tym zwłaszcza prasy codziennej, w największym zakresie omija tabloidy (choćby polski „Fakt” czy podobny mu brytyjski „The Sun”).

Media w dobie globalizacji działają według jednolitych zasad; prezentują informacje w taki sam sposób, oferują identyczne (często na zasadzie wykupu 
licencji) programy rozrywkowe, promują z reguły te same idee światopoglądowe, przyczyniając się walnie do wspomnianej wyżej homogenizacji kultur. Jedną z widocznych cech nie tylko współczesnych mediów, ale i kultury w szerokim zakresie jest inwazja obrazów, piktogramów, dominacja ikonosfery. Dzisiejsza kultura jest kulturą obrazu. Środowisko obrazu jest główną składową życia człowieka, skala rozpowszechnienia się i panowania obrazów jest trudna do przecenienia. Rozwój ikonosfery łączy się z zawężaniem obszaru oddziaływania logosfery, czyli środowiska słowa (Lepa 2003, s. 181 i nast.), tymczasem prasa, zwłaszcza prasa tradycyjna (pominąć należy tu prasę bulwarową), jest właśnie obszarem słowa, obrazy są tylko jej dopełnieniem, nie istotą.

Marginalizacja logosfery w życiu człowieka pociąga za sobą wiele negatywnych zjawisk. Ogólny spadek czytelnictwa prowadzi do półanalfabetyzmu (co przejawia się w błędnej ortografii, trudnościach w pisaniu i/lub czytaniu) lub funkcjonalnego analfabetyzu, czyli problemów ze zrozumieniem i zinterpretowaniem nieskomplikowanych przekazów. Okazuje się, że problem braku odpowiednich kompetencji kulturowych, czyli umiejętności praktycznego użytkowania, wykorzystania elementów kultury, jak Piotr Sztompka (2005, s. 241) określił funkcjonalny analfabetyzm, dotyczy znacznego odsetka współczesnych społeczeństw. Na przykład badania przeprowadzone w 2000 r. w Wielkiej Brytanii przez profesor Lorettę Todd $z$ uniwersytetu ulsterskiego na zlecenie domu wydawniczego Bloomsbury pokazały, że 15\% ankietowanych w wieku 15-21 lat to półanalfabeci. Dla porównania - w 1912 r. ówcześni inspektorzy ankietując taką samą liczbę uczniów i absolwentów szkół z tej samej grupy wiekowej ustalili, że półanalfabeci stanowią ledwie $2 \%$ ogółu przebadanych ${ }^{15}$.

Co interesujące, rzeczywisty brak umiejętności płynnego czytania, pisania i znajomości zasad ortograficznych jest odwrotnie proporcjonalny do wysokiego mniemania nastolatków na temat swoich zdolności: siedmiu na dziesięciu ankietowanych stwierdziło, że ma dużą wprawę $\mathrm{w}$ poprawnym pisaniu i literowaniu słów, ale $\mathrm{w}$ praktycznym ćwiczeniu żadnemu $z$ nich nie udało się wskazać wszystkich czternastu błędów w pisowni słów w przedstawionym im tekście. Zastanawiające, że wzrostowi wśród młodzieży problemów z pisaniem i czytaniem (czyli umiejętnościami fundamentalnymi dla przyswajania wiadomości $\mathrm{w}$ procesie edukacji) nie towarzyszy spadek wiedzy wyrażający się w słabszych ocenach. Wyniki egzaminów maturalnych w Wielkiej Brytanii (ogłoszone niemal równolegle $z$ wynikami cytowanych badań) wskazują na coraz wyższy procent dobrych i bardzo dobrych ocen i to przez kolejny rok z rzędu. Za możliwy powód takiego stanu rzeczy uznano między innymi sprawdzanie poprawności pisowni słów przez programy komputerowe. Cytowany przez dziennik „The Scotsman” David Eaglesham - generalny sekretarz szkockich władz oświatowych — zwrócił uwagę na odmienność kryteriów sto-

15 www.psychologia.edu.pl za PAP (serwis z 22.08.2001). 
sowanych w nauczaniu obecnie i w 1912 r.: „W przeszłości uczniom polecano wykucie podstawowej wiedzy i zdanie egzaminu. Obecnie akcent kładzie się na innego rodzaju umiejętności, takie jak posługiwanie się komputerem i zdolność do wyrażenia siebie" 16 .

Półanalfabetyzm nie jest w Wielkiej Brytanii zjawiskiem nowym, co więcej, jest postrzegany jako problem społeczny. W 2000 r. rządowa grupa robocza powołana do zbadania zjawiska wtórnego analfabetyzmu wśród dorosłych oceniła, że 7 mln Brytyjczyków nie radzi sobie w stopniu zadowalającym z czytaniem, pisaniem lub prostymi wyliczeniami. Co najmniej $2 \mathrm{mln} z$ nich to całkowici analfabeci, którzy nie rozumieją podstawowych informacji, na przykład na opakowaniach produktów dostępnych w supermarketach lub rozkładu jazdy środków komunikacji miejskiej. Analfabeci stanowią 60\% więźniów w Anglii i Walii. Co niepokojące, badania Todd dowodzą, że sytuacja pogarsza się z pokolenia na pokolenie. $W$ teście, który miał zbadać umiejętność wskazania poprawnej pisowni tego samego słowa pisanego na trzy różne sposoby, ankietowani w grupie wiekowej 41-50 lat wypadli dużo lepiej niż grupa w wieku 15-30 lat ${ }^{17}$.

Należy pamiętać, że zachowanie właściwych relacji między logosferą a ikonosferą, dążenie do tego, by funkcjonowały one na zasadzie komplementarności, jednak z położeniem wyraźnego akcentu na udział jednostki w środowisku słowa, z punktu widzenia rozwoju osobowości człowieka wydaje się najkorzystniejsze.

$\mathrm{Na}$ generalne pogarszanie się kondycji rynkowej wydawnictw prasowych ma wpływ wiele współwystępujących czynników. Do najistotniejszych należą rosnąca konkurencja ze strony internetu i przeobrażenia kulturowe współczesnych społeczeństw. Nadużyciem byłoby twierdzenie, iż dzisiejsze społeczeństwa opierają swe funkcjonowanie jedynie na starożytnej zasadzie panem et circenses. Wielu specjalistów w dziedzinie nauk społecznych dostrzega jednak trafność tez głoszonych na temat społeczeństwa masowego między innymi przez Ortegę y Gasseta. Niepokojący jest, według nich, kierunek rozwoju młodych pokoleń i stan świadomości współczesnych jednostek, „przeciętność” i miałkość, które są normą. Genezy tych zjawisk upatrują w znacznej mierze w działaniu współczesnych mediów. Wskazują, że problem ten winien stać się przedmiotem dyskusji i działań kompetentnych gremiów oraz środowisk decydenckich ${ }^{18}$. Jeśli uznamy powyższą charakterystykę za trafną, to można

16 www.psychologia.edu.pl za PAP (serwis z 22.08.2001).

17 www.psychologia.edu.pl za PAP (serwis z 22.08.2001).

$18 \mathrm{Na}$ gruncie polskim realizowana była kampania społeczna pod hasłem „Poczytaj mi mamo” zachęcająca do czytania dzieciom przynajmniej 20 minut dziennie. Jednak w odczuciu wielu prak- 
obawiać się, że nastąpi dalszy spadek zainteresowania wśród młodych ludzi zdobywaniem wiedzy i rozszerzaniem horyzontów przez „obcowanie ze słowem”, a w konsekwencji - znikomy odbiór prasy. Widzący „szklankę do połowy pełną" stwierdzą zapewne, że nie da się zatrzymać przeobrażeń społecznych, u których podstaw leżą zmiany techniczne, między innymi w dziedzinie mediów, i że nie muszą one oznaczać marginalizacji dotychczasowych wartości, przyzwyczajeń, kanonów kulturowych. Ich przeciwnicy skonstatują, że nasza kultura wkrótce może stać się atrapą, karykaturą samej siebie sprzed lat, co nie tylko zmniejszyłoby siłę oddziaływania i znaczenie w świecie „starych" mediów, ale odcisnęłoby się także na poziomie i charakterze umysłowości przyszłych pokoleń.

\section{BIBLIOGRAFIA}

Bauer Zbigniew, 2008, Rozwój środków komunikowania, w: Zbigniew Bauer, Edward Chudziński (red.), Dziennikarstwo i świat mediów, Universitas, Kraków.

Bendyk Edwin, 2004, Antymatrix. Człowiek w labiryncie sieci, Wydawnictwo WAB, Warszawa.

Czubakowska Sylwia, Osipczuk Małgorzata, 2002, Infoholizm - plaga XXI wieku, www.psychotekst.com.

Dobek-Ostrowska Bogusława (red.), 2001, Nauka o komunikowaniu. Podstawowe orientacje teoretyczne, Wydawnictwo Uniwersytetu Wrocławskiego, Wrocław.

Durning Alan, 1992, How Much Is Enough: The Consumer Society and the Future of Earth, Worldwatch Institute, New York.

Goban-Klas Tomasz, 2008, Media $i$ komunikowanie masowe. Teorie $i$ analizy prasy, radia, telewizji i Internetu, Wydawnictwo Naukowe PWN, Warszawa.

Grynkiewicz Tomasz, 2006, Gazety na e-papierze już w 2007 roku?, „Gazeta Wyborcza”, 3 lipca.

Iłowiecki Maciej, 2003, Krzywe zwierciadto. O manipulacji w mediach, Gaudium, Lublin.

Jenkins Henry, 2007, Kultura konwergencji. Zderzenie starych i nowych mediów, tłum. Małgorzata Bernatowicz, Mirosław Filiciak, Wydawnictwa Akademickie i Profesjonalne, Warszawa.

Katz Eliu, 1990, Badania komunikowania od czasów Lazarsfelda, „Przekazy i Opinie”, nr 3-4.

Kowalski Tadeusz, 2006, Prasa codzienna - rozwój w cieniu nowych technologii, w: Tadeusz Kowalski, Bohdan Jung (red.), Media na rynku. Wprowadzenie do ekonomiki mediów, Wydawnictwa Akademickie i Profesjonalne, Warszawa.

Lepa Adam, 2003, Pedagogika mass mediów, Archidiecezjalne Wydawnictwo Łódzkie, Łódź.

Lindstrom Martin, 2009, Zakupologia. Prawda i kłamstwa o tym, dlaczego kupujemy, thum. Magdalena Zielińska, Znak, Kraków.

Meyer Philip, 2004, The Vanishing Newspaper: Saving Journalism in the Information Age, University of Missouri Press, Columbia.

tyków i teoretyków jej zasięg (skoncentrowanie się na jednym medium i stosunkowo krótki czas praktykowania) był niewystarczający. 
Paprocka Marta, 2005, Ile czasu pozostało tradycyjnym mediom?, www.wiadomosci. mediarun.pl [14.11.2005].

Pisarek Walery, 1983, Analiza zawartości prasy, Ośrodek Badań Prasoznawczych, Kraków. Siuda Piotr, 2007, Fanfiction - przejaw medialnych fandomów, w: Włodzimierz Gruszczyńska, Anna Hebda (red.), Cztowiek a media. Obserwacje - wizje — obawy, Instytut Dziennikarstwa UW, Warszawa.

Sowula Grzegorz, 2008, Biblioteka na ekranie, „Rzeczpospolita”, 6-7 września.

Spychalski Gedymin B. (red.), 2002, Zarys historii myśli ekonomicznej, Wydawnictwo Naukowe PWN, Warszawa, rozdz. Teoria ekonomiczna Keynesa i jego następców (keynesistów).

Stasiak Piotr, 2006, Człowiek z ekranu, „Polityka”, 2 grudnia.

Sztompka Piotr, 2005, Socjologia. Analiza społeczeństwa, Znak, Kraków.

\section{THE PRESS AND THE INTERNET: COMPETITION OR COMPLEMENTARY?}

\section{Summary}

The author's considerations concern the relationship in the period of fundamental changes in technology and culture between the press and the Internet - two media which are different in both form and function. The influence of the press is changing which is shown in the diminishing sales worldwide, and the significance of the Internet is increasing. The systematic contraction of the market for the press is caused by several factors. The competitiveness of the Internet increases with the increasing participation of the young generation in social life. At the same time there is a deep cultural transformation underway which involves the increasing domination of the pictorial environment, the marginalization of the word, the shallowness which replaces previous values. There are many possible futures for the press. The most probable is that it will adapt in form and will continue to exist in the media market. The influence of the press on future societies remains unclear.

\section{Key words/słowa kluczowe}

press / prasa; Internet / internet; press market / rynek prasowy; readership / czytelnictwo; globalisation / globalizacja; change / zmiana; youth / młodzież 